\title{
HORMONAL IMBALANCE? BALANCING FREE TRADE AND SPS MEASURES AFTER THE DECISION IN HORMONES
}

\author{
Iain Sandford
}

The Agreement on the Application of Sanitary and Phytosanitary Measures was negotiated during the Uruguay Round of multilateral trade negotiations to ensure that measures taken to protect humans and animals from food-borne risks, and to protect plants, animals and people from the risks of pests and diseases (SPS measures) were imposed only where they were justified. As such, the Agreement implicitly struck a balance between the freedom of World Trade Organization (WTO) Members to impose such legitimate measures and the objective of minimising trade disruptions.

This paper explores how this implicit balance was tested in the first SPS case to come before the WTO's new dispute settlement system - European Communities - Measures Concerning Meat and Meat Products (Hormones). This paper examines the reasoning of both the Panel and Appellate Body considering the case and concludes that the final decision of the Appellate Body moved the balance too far in favour of Members' right to impose trade restrictive SPS measures.

\section{INTRODUCTION}

Ever since Adam Smith challenged the mercantilist paradigm, economists have argued the benefits of free trade. Also desirable, however, are measures taken to protect humans, animals and plants from health risks. Because the implementation of health measures frequently raises barriers to trade, there is considerable friction between these two priorities. The multilateral trading system has, nevertheless, always allowed States discretion to impose health protection measures. Striking the correct balance has been one of the pervading challenges.

* This is an edited version of a paper submitted in partial fulfilment of VUW LLM requirements. 
This paper considers a sub-set of the rules affecting measures designed to protect plants, animals and people from health risks. This paper examines the rules affecting measures taken to protect humans and animals from food-borne risks, and those taken to protect humans, animals or plants from pests and diseases. After the Uruguay Round of multilateral trade negotiations and the establishment of the World Trade Organization (WTO), these "sanitary and phytosanitary" or "SPS" measures came to be governed by the Agreement on the Application of Sanitary and Phytosanitary Measures (the SPS Agreement). ${ }^{1}$

The SPS Agreement explicitly recognises the rights of WTO Members to impose SPS measures, but attempts to strike a balance between this right and the negative trade effects that the imposition of such measures entails. It thus provides for certain objective criteria to be applied before measures are considered. When measures come to be imposed, the SPS Agreement requires Members to make them as least trade restrictive as possible.

The main part of this paper considers how the SPS Agreement survived its first encounter with the new dispute settlement provisions of the WTO - the decision in European Communities - Measures Concerning Meat and Meat Products (Hormones). ${ }^{2}$ In particular, the paper examines how the WTO dispute settlement process interpreted the negotiated balance in the Agreement.

At first instance in the WTO dispute settlement process, a robust approach was taken to the disciplines on the imposition of SPS measures. On appeal the balance swung back in the other direction and a more restrictive interpretation of these disciplines was adopted. The WTO's Appellate Body stepped back from the transparency requirements emphasised by the Panel. Instead the Appellate Body stressed the right of Members to impose SPS measures. This makes it harder to trade. Governments, however, retain considerably more freedom.

This paper concludes by suggesting that the Appellate Body's decision went too far. While certain findings of the Panel were inadequate and required revision, the Panel's

1 The SPS Agreement is an integral part of the Marrakesh Agreement Establishing the World Trade Organisation (the WTO Agreement). The WTO Agreement entered into force on 1 January 1995 and can be found at 1995 NZTS 17.

2 Complaint by Canada WT/DS48/CAN; complaint by the United States WT/DS26/R/USA; Appellate Body Report, AB-1997-04 WT/DS26/AB/R; WT/DS48/AB/R. The Panel reports, as modified by the Appellate Body Report, were adopted by the WTO's Dispute Settlement Body on 13 February 1998. Despite its importance, the decision in Hormones has to date received little attention in the leading journals. Two useful commentaries on the decision are, however, contained in D McNeil "The WTO Decision on the EU's Hormone Ban: Is Anything Left of the SPS Agreement" in (1998) XIII The Agricultural Law Leter, 1; and in (1998) 2 ITLR 719. 
general approach would have ensured that only those measures which were scientifically robust could be imposed. By contrast the Appellate Body's decision weakens the moderating role that objective scientific assessments could have played in the application of SPS measures. Without this objectivity, the goal of the SPS negotiators to ensure that otherwise unjustifiable restrictions to trade would not be disguised as SPS measures will be difficult to attain.

\section{THE SPS AGREEMENT}

\section{A History}

It is important to understand why the SPS Agreement was negotiated. Historically, contracting parties to the General Agreement on Tariffs and Trade (GATT) ${ }^{3}$ retained considerable freedom to impose SPS measures. Nevertheless, because trade in agricultural goods was not fully integrated into the GATT system, there was little need to check this freedom because other barriers prevented trade in agricultural products regardless of their SPS status. The integration of agricultural trade into the multilateral trading system at the time of the Uruguay Round meant, however, that new disciplines were required to prevent abuse of contracting parties' relative freedom to impose SPS measures.

\section{Measures necessary to protect human, animal or plant health under the GATT}

Measures taken to protect human, animal or plant health (of which SPS measures are an important sub-set) are often inconsistent with fundamental principles contained in the GATT. For example, such measures often take the form of a ban on the importation of products. On its face, this is inconsistent with the general prohibition on the application of quantitative restrictions contained in Article XI of the GATT. Similarly, a measure might discriminate between the produce of different countries on the grounds that each of the countries has a different pest or disease status. This seems inconsistent with the GATT Article I obligation to give most-favoured-nation treatment to all parties to the Agreement. The importance of such measures has, however, always been recognised and the GATT inconsistency of such measures is dealt with by a broad general exception.

3 Between 1948 and 1994 the GATT was the principal instrument governing the multilateral trading system. As well as referring to the General Agreement itself, the name "GATT" also came to refer to the de facto international organisation composed of the "CONTRACTING PARTIES" to the General Agreement. The original text of the GATT (as amended at various times throughout its history) was renamed "GATT 1947" by the WTO Agreement. The WTO Agreement now incorporates "GATT 1994", which is the text of GATT 1947, together with the supplementary Understandings and Instruments concluded between 1947 and the beginning of the Uruguay Round as well as the supplementary Uruguay Round Understandings and Marrakesh Protocol. 
Article XX of the GATT 1947 thus sets out:

Subject to the requirement that such measures are not applied in a manner which would constitute a means of arbitrary or unjustifiable discrimination between countries where the same conditions prevail, or a disguised restriction on international trade, nothing in this Agreement shall be construed to prevent the adoption or enforcement by any contracting party of measures:

(b) necessary to protect human, animal or plant life or health;

Prior to the establishment of the WTO, GATT practice suggests that this provision was taken to emphasise the ability of States to take actions necessary to protect human, animal or plant life. The disciplines that it applied - principally the requirement that such measures be necessary - were vague at best. It also appears to have been difficult to enforce - as is indicated by the dearth of dispute settlement cases considering the provision. 4

Of course, the difficulty in bringing cases within the terms of the GATT only partly explains the absence of GATT dispute settlement jurisprudence on the application of SPS measures. In the context of the pre-Uruguay Round GATT regime, Article $X X(b)$ of the GATT would undoubtedly have had most significance in regulating barriers affecting agricultural trade. Agricultural trade, however, was never really integrated into the GATT system. While formally, agricultural goods fell within the general rules, a plethora of special exemptions - some of general application, others applying to specific contracting parties - meant that most disciplines did not apply. Even in the 1980s, when the Uruguay Round began, agricultural trade was characterised by the prevalence of

4 Prior to the conclusion of the Uruguay Round, Art XX $(b)$ appears to have been considered in only one adopted and two unadopted dispute settlement reports. These were Thailand - Restrictions on Importation of and Internal Taxes on Cigarettes (adopted 7 November 1990) BISD 37S/200, United States - Restrictions on Imports of Tuna (ciruclated 3 September 1991, not adopted) DS 29/R. The first of these cases dealt with the regulation of cigarettes. The latter two dealt with the protection of the environment beyond the territory of the Contracting Party involved. As it noted below at part II B, these cases would not fall within the SPS Agreement were they to arise today and so are not considered here in any depth. Art XX also appears to have been relied upon in Uruguayan Recourse to Art XXIII (adopted 16 November 1962) BISD 11S/95 and Uruguayan Recourse to Art XXIII (adopted 3 March 1965) BISD 13S/35 although it is not mentioned in the text of the reports: see P Pescatore, W Davie and \& Lowenfeld Handbook of WTO/GATT Dispute Settlement (Kluwer, New York, 1997) Part 2 "The Repertory", 32-34 \& 37-38 respectively. Since the conclusion of the Uruguay Round Art XX (b) has taken on a new life in WTO dispute settlement proceedings: see United States - Standards for Reformulated and Conventional Gasoline WT/DS2/9 (adopted 20 May 1996); and United States - Import Prohibition on Certain Shrimp and Shrimp Products WT/DS15/R (commonly referred to as "Shrimp-Turtle", Panel Report issued on 15 May 1998 but subject to review by the Appellate Body at the time of writing). 
extensive non-tariff barriers to trade (typically in the form of quantitative restrictions), export competition distorted by the use of export subsidies and a web of country specific preferences granted to particular agricultural exporting countries for particular commodities. ${ }^{5}$ In this stunted agricultural trading regime, the absence of effective rules for the regulation of SPS measures was of only subsidiary importance because trade restrictions could be imposed with or without an SPS justification.

\section{Measures necessary to protect human, animal or plant health underthe Tokyo Round "Standards Code"}

By the time of the Tokyo Round of multilateral trade negotiations (1973-79) it came to be recognised that greater discipline was required on the ability of contracting parties to apply technical barriers to trade. ${ }^{6}$ In his report at the conclusion of the Tokyo Round, Olivier Long - the then Director-General of the GATT - noted: ${ }^{7}$

international trade can be complicated and inhibited by disparities between regulations, adopted at local, State, national or regional levels; by insufficient information on the often complex and detailed requirements; by the introduction of regulations without allowing time for producers, especially foreign ones, to adjust their production; by frequent changes to regulations which create uncertainty; by the drawing up of regulations in terms of design rather than performance in order to suit the production methods of domestic suppliers, thus causing difficulties to suppliers using different techniques; by exacting testing requirements; by the denial of access to certification systems; and finally by the manipulation of regulations, testing and certification to discriminate against imports.

The Tokyo Round's response to these complicating and inhibiting factors was the Agreement on Technical Barriers to Trade (commonly referred to as the Tokyo Round

5 See generally W Davey, "The Rules of Agricultural Trade in the GATT", reprinted with permission from Mawsayosi Homna, Akio Shimizu \& Hideki Funatsu (eds) GATT and Trade Liberalisation in Agriculture (1993) in J Jackson, W Davey, \& A Sykes, Legal Problems of International Economic Relations (West Publishing, St Paul 1994), 1161-1169; W Davey "The World Trading System: A History of the Uruguay Round (WTO, Geneva, 1995), 104-105; and J Breen "Agriculture" in T Stewart (ed) The GATT Uruguay Round: A Negotiating History 1986-1992 (Kluwer, Deventner, 1993), 133-171.

6 "Technical barriers to trade" is broad term encompassing measures such as those necessary for the protection of humna, animal and plant health, measures dealing with issues like protection of the environment, product quality, production methods as well as measures dealing with consumer information and the prevention of deceptive practices.

7 Report of the Director-General of GATT, The Tokyo Round, (1979) 26-63 cited in Jackson Davey \& Sykes, above n 5, 538-539. 
"Standards Code"). ${ }^{8}$ The Standards Code aimed not to preclude Parties to it from adopting measures, but aimed to increase the transparency and predictability of such measures by disciplining their application. To this end, the Standards Code covered inter alia technical requirements relating to food safety, and measures designed to protect plant or animal health as well as related issues such as inspection procedures and labelling. ${ }^{9}$ The principal obligation was to "ensure that technical regulations and standards are not prepared, adopted or applied with a view to creating obstacles to international trade". ${ }^{10}$ Parties to the Code undertook to base their measures on relevant international standards, where they existed, except where such standards were "inappropriate" - for example in situations where the Party perceived a need for a higher level of protection. ${ }^{11}$ Members undertook certain notification requirements with respect to their technical regulations and standards. ${ }^{12}$ The Code also provided an enhanced dispute settlement procedure which incorporated the possibility of establishing a "technical experts group". ${ }^{13}$

Importantly, from a human, animal and plant health point of view, a technical experts group could make "findings concerning the detailed scientific judgments involved [with respect to a particular measure], whether the measure was necessary to protect human, animal or plant life or health, and whether a legitimate scientific judgment was involved". ${ }^{14}$ This provision usefully recognised the important role of objective scientific

8 The Standards Code entered into force on 1 January 1980 and can be found at 1979 NZTS 18. The Code was superseded by the Agreement on Technical Barriers to Trade (the TBT Agreement) concluded as part of the WTO Agreement when the latter Agreement entered into force on 1 January 1995. For a brief summary of some key differences between the Standards Code and the new TBT Agreement, see below at n 27.

9 Standards Code, Annex 1, definitions 1-3.

10 Standards Code, Art 2.1. "Technical regulation" was defined in Annex 1 of the Code as "[a] technical specification, including applicable administrative provisions, with which compliance is mandatory". "Standard" was defined as "[a\} technical specification approved by a recognised standardising body for repeated or continuous application, with which compliance is not mandatory". "Technical specification" was in turn defined as "[a] specification contained in a document which lays down characteristics of a product such as levels of performance, safety or dimensions. It may deal exclusively with terminology, symbols, testing and test methods, packaging, marking or labelling requriements as they apply to a product".

11 Standards Code, Art 2.2.

12 Standards Code, Arts 2.5 and 10.

13 Standards Code, Art 14, Annex 2 and Annex 3.

14 Standards Code, Art 14.9. 
assessments in determining whether something is actually "necessary to protect human, animal or plant life or health" and not simply an otherwise unjustifiable barrier to trade.

This was certainly an improvement on the GATT simpliciter. It had limitations, nonetheless. The Standards Code still covered agricultural trade only insofar as it fell within the GATT system. Further, to be subject to - or indeed to benefit from - the Code's provisions, a country had to be a Party to it. But not all GATT contracting parties were Parties to the Standards Code. In fact, while it was the most well subscribed of the six Tokyo Round Codes, Parties to the Standards Code never represented more than half the total GATT "membership".

The principal limitation of the Standards Code, however, related to the imprecision with which its disciplines were defined. An obligation to "ensure that technical regulations and standards are not prepared, adopted or applied with a view to creating obstacles to international trade" is all well and good, but it is very difficult to demonstrate that a technical regulation or standard has been prepared, adopted or applied with such a view. Moreover, the disciplines only related to technical regulations and standards as defined. Each of the definitions was limited in that they only applied to documents laying down product characteristics. ${ }^{15}$ They did not apply to the processes and production methods that were used to create the product, where these did not come to be embodied in the physical characteristics of the final good. The only discipline on these sorts of measures was a reference in the dispute settlement provisions suggesting that defining specifications in terms of process and production method should not be used to circumvent the other obligations of the Code. ${ }^{16}$ The history of the Hormones case reveals that such a technique could effectively be used to avoid the formation of a technical experts group to consider more closely the basis of a measure.

\section{The Uruguay Round}

The Uruguay Round broke new ground for the multilateral trading system. Whereas the history of GATT was pervaded by very high levels of protection in relation to agricultural goods, the Uruguay Round moved to reduce protection and "bring more discipline and predictability to world agricultural trade". ${ }^{17}$ With this development there was an increased risk that countries would seek to replace old protective measures with new trade restrictions disguised as measures protecting human, animal or plant health.

15 See above $\mathrm{n} 10$.

16 Standards Code, Art 14.25.

17 Ministerial Declaration of the Uruguay Round issued at Punta del Este on 20 September 1986 (more commonly referred to as the "Punta del Este Declaration"), Part I.D, "Agriculture". 
The Punta del Este Declaration thus mandated the negotiations to focus on "minimising the adverse effects that sanitary and phytosanitary regulations and barriers can have on trade in agriculture, taking into account the relevant international agreements". ${ }^{18}$

A consideration of the SPS negotiations reveals that there was high degree of consensus on the means by which an SPS agreement would achieve this goal. The working group quickly resolved that international standards should form the basis of SPS measures where appropriate; that where compliance with an international standard was not appropriate, measures should take into account scientific evidence; that different measures imposed by other countries should be accepted as equivalent where they could be demonstrated to achieve similar results; that measures should aim to minimise trade restrictions; and that measures should be as transparent as possible and should be publicised and monitored by a GATT body. ${ }^{19}$

But while it was clear that science would have a role in the development of SPS measures, a more challenging issue related to what other criteria might be taken into account. An illustration of this is the tension between the Cairns Group ${ }^{20}$ submission that: ${ }^{21}$

food grading, consumer preference, consumer information, animal welfare and religious and moral issues ..., are not SPS matters and should not be dealt with in th[e] context [of an SPS agreement]

and the submission of the European Communities (EC) that it may merely: ${ }^{22}$

18 Above $n 17$

19 A useful summary of various written statements made by participants in the SPS working group prior to the drafting of the initial draft SPS text is contained in Negotiating Group on Agriculture Working Group of Sanitary and Phytosanitary Regulations and Barriers - Synoptic Table of Proposals Relating to Key Concepts - Note by the Secretariat MTN.GNG/NG5/WGSP/W/17 (30 April 1990). See more generally Croome, above n 5, 237; and Breen, above n 5, 172-192.

20 Argentina, Australia, Brazil, Canada, Chile, Colombia, Hungary, Indonesia, Malaysia, New Zealand, the Phillippines, Thailand and Uruguay.

21 Negotiating Group on Agriculture - Working Group of Sanitary and Phytosanitary Issues - Supplementary Communication of the Cairns Group MTN.GNG/NG5/W/164 summarised in the Synoptic Table above $\mathrm{n} 19,3$.

22 Negotiating Group on Agriculture - Submission of the European Communities on Sanitary and Phytosanitary Regulations and Measures MTN.GNG/NG5/W/146 summarised in the Synoptic Table above no 19, 3 . 
be necessary to identify the sanitary or phytosanitary elements (i.e. those designed to protect life or health) [in a measure] from other elements relating to quality assurance (e.g. composition, grading and labelling requirements) or to fair trade or to the prevention of fraud.

This tension had not been resolved by the time the initial draft SPS text ${ }^{23}$ was circulated. Accordingly, at paragraph 21 the draft text square bracketed the possibility of a Government taking into account "other economic considerations and genuine consumer concerns" when establishing or maintaining SPS measures.

The final text reveals that this square bracketed text was removed. One might assume that this meant the Cairns Group approach of separating issues like consumer concerns or animal welfare from the imposition of SPS measures had prevailed. However, language making it clear that such factors cannot be taken into account is also absent from the final text. This came to be of some significance in the Hormones decisions.

Another difficult issue related to the extent to which contracting parties would be able to deviate from international standards, where they existed. The EC favoured allowing governments some flexibility in this respect. The US too came to support this position. On the other side of the debate, the Cairns Group favoured maximum harmonisation and wanted to allow little deviation. ${ }^{24}$

On this point the EC and US position prevailed and the final text makes it clear that Members of the WTO can deviate, subject to certain disciplines, from international standards to achieve a higher level of protection. The Agreement is not explicit, however, on who bears the burden of demonstrating compliance or otherwise with the disciplines. While the sparse literature dealing with the SPS Agreement does not really pick up on this point, anecdotal evidence suggests that many thought that deviation from international standards was an "exception" to the general obligation to base measures on international standards. ${ }^{25}$ Applying the allocation of the burden of proof used for the exceptions in Article XX of the GATT, many expected that the burden would fall on the party seeking to rely on the exception.

After seven years of negotiations, the Uruguay Round was successfully concluded at Marrakesh, Morocco on 15 April 1994 with the signing of the WTO Agreement. As well

23 Negotiating Group on Agriculture - Working Group of Sanitary and Phytosanitary Regulations and Barriers - Draft Text on Sanitary and Phytosanitary Measures MTN.GNG/NG5/WGSP/7 (20 November 1990).

24 See Synoptic Table above n 19, 6. See also Breen, above n 5, 201.

25 One might observe that the expectation apparent in this anecdotal evidence is supported by the fact that the Panel in Hormones determined that deviation from international standards was in fact an exception to the generally applicable rules. See below at Part III D2(a). 
as incorporating the SPS Agreement and a range of other Multilateral Trade Agreements, the

WTO Agreement established a new robust dispute settlement procedure. ${ }^{26}$ The new procedure draws on the pre-existing GATT regime's use of consultations and dispute settlement Panels. The new regime also established a standing Appellate Body to review questions of law arising out of Panel decisions. The interplay between the development of the SPS Agreement and the new dispute settlement procedures forms the basis of the main part of this paper.

\section{B Coverage of the SPS Agreement}

As the name suggests, the SPS Agreement covers the application of SPS measures. The Agreement accordingly supplements, but does not entirely replace, the general exception in Article XX of the GATT (now GATT 1994) and the regime created by the Agreement on Technical Barriers to Trade (now reshaped and hereafter referred to as "the TBT Agreement"). ${ }^{27}$ In the SPS Agreement "[s]anitary or phytosanitary measure" is defined as: ${ }^{28}$

Any measure applied:

26 There is an increasing amount of material available on the nature of the new WTO dispute settlement regime. A very useful recent publication incorporating the views of many leading commentators is J Cameron \& K Campbell (eds) Dispute Settlement in the WTO (Cameron May, London, 1998).

27 The new TBT Agreement is different from the Tokyo Round Standards Code in a number of ways. The new TBT Agreement applies to measures taken to protect the health of humans animals and plants, but only to the extent that these issues are not covered by the SPS Agreement (TBT Agreement, Art 1.5). The new TBT Agreement is thus not explored in any great depth in this paper. It is useful to note, however, that many of the shortcomings of the old Standards Code were addressed during the negotiation of the TBT Agreement in the Uruguay Round. The definitions of "technical regulation" and "standard" were revised to include process and production methods. The problems relating to limited membership were solved by the Uruguay Round's "single undertaking" approach - whereby all WTO Members signed up to all of the Multilateral Trade Agreements when accepting the WTO Agreement. The principal obligation in relation to technical regulations (now found in Art 2.2) is broader than Art 2.1 of the Standards code but may still be difficult to enforce. The relevant part of Art 2.2 of the TBT Agreement reads "Members shall ensure that technical regulations are not prepared, adopted or applied with a view to or with the effect of creating unnecessary obstacles to international trade. For this purpose, technical regulations shall not be more trade-restrictive than necessary to fulfill a legitimate objective, taking into account of the riks non-fulfillment would create".

SPS Agreement, Annex A - Definitions. Definition 1. 
(a) to protect animal or plant life or health within the territory of the Member from risks arising from the entry, establishment or spread of pests, diseases, disease-carrying organisms or disease-causing organisms;

(b) to protect human or animal life or health within the territory of the Member from risks arising from additives, contaminants, toxins or disease-causing organisms in foods, beverages or feedstuffs;

(c) to protect human life or health within the territory of the Member from risks arising from diseases carried by animals, plants or products thereof, or from the entry, establishment or spread of pests; or

(d) to prevent or limit other damage within the territory of the Member from the entry, establishment or spread of pests.

Sanitary or phytosanitary measures include all relevant laws, decrees, regulations, requirements and procedures including, inter alia, end-product criteria; processes and production methods; testing, inspection, certification and approval procedures; quarantine treatments including relevant requirements associated with the transport of animals or plants, or with the materials necessary for their survival during transport; provisions on relevant statistical methods, sampling procedures and methods of risk assessment; and packaging and labelling requirements directly related to food safety.

The SPS Agreement thus covers a broad range of "food safety" issues. It also covers situations involving the entry into a Member's territory of pests, diseases, disease carrying plants, animals and organisms as well as disease causing organisms. It does not cover certain other health and safety measures such as those taken against disease causing (as opposed to carrying) plants. Nor does it cover the protection of the environment beyond the territory of a Member. Issues such as tobacco regulation thus fall outside of the scope of the SPS Agreement, as do measures protecting animals living in the high seas. Trade related aspects of these issues continue to be regulated by the residual regime of the GATT 1994 and the TBT Agreement.

\section{The Balance in the SPS Agreement}

With the integration of agricultural trade into the multilateral trading system, there was a need to more clearly define the balance between a Member's right to address risks to human, animal and plant health and the objective of minimising the negative trade impact that SPS measures often have. The text of the SPS Agreement thus reiterates the right of a Member to take SPS measures, but subjects this right to certain rules.

In terms of implementing procedures to give effect to the Agreement, the nature of these 
rules means that it is relatively easy to comply. ${ }^{29}$ The SPS Agreement gives guidance as to the steps that must be followed before a measure is adopted. For example, in certain situations a Member will need to perform a risk assessment before imposing a measure. However, because the precise nature of the balance between the two underlying objectives of the Agreement is more implicit, it remains difficult to ascertain whether a measure adopted with reference to an appropriate procedure is actually warranted. That is to say, even in a situation where a risk assessment has been performed, it might still be difficult to say that the measure is justified by the assessment. While this almost certainly made the Agreement easier to negotiate, it left determination of the fundamental issue the balance between the right to impose SPS measures and the objective of liberalising trade - to the dispute settlement process.

\section{Minimising negative trade impact}

Because SPS measures are often barriers to trade, the Uruguay Round negotiators sought (in accordance with the Punta del Este Declaration mandate) to place disciplines on their application to minimise their negative effects on trade. Such negative effects might be deliberate. A Member could utilise a "disguised restriction on international trade" to protect its domestic industry from foreign competition. But negative trade effects need not flow from the sinister forces of protectionism. They might be innocent for example, arising out of the fact that different countries had different measures affecting the same trade item, increasing the compliance costs of the item's manufacturer.

To minimise negative trade effects, the SPS Agreement seeks to ensure greater transparency - stripping the veil from disguised restrictions - as well as greater consistency and predictability - minimising compliance costs. It seeks to achieve these goals through the application of a number of rules. These are outlined below.

29 Of course, it should be pointed out that in both of the SPS cases to come before the WTO dispute settlement process to date - Hornones and Australia - Measures Affecting Importation of Salmon WT/DS18/R (Panel Report issued 12 June 1998 but subject to review by the Appellate Body at the time of writing) - the measures adopted by the edefending Member were found to be deficient on the grounds that they did not go through all of the procedural steps mandated by the SPS Agreement. Nevertheless in each of the cases there appears to have been other imperatives affecting the actions of the defending Members. This seems to have been recognised in the arbitration following adoption of the Hormones Reports - European Communities - Measures Concerning Meat and Meat Products (Hormones): Arbitration Under Art 21/3(c) of the Understanding on the Rules and Procedures Governing the Settlement of Disputes: Award of the Aribtrator WT/DS26/15; WT/DS48/13 (29 May 1998). The Arbitrator said in para 40 that "[c]ontrary to the European Communities' arguments that it did not know that hormone-specific and residue specific assessments were required by Art 5.1 of the SPS Agreement, the European Communities did not need to wait for the Hormones Appellate Body Report, above n 2, before commissioning scientific studies to supports its ban" (footnote omitted). 


\section{(a) Objective criteria}

Science is given a central role in the SPS Agreement. Article 2 - Basic Rights and Obligations - requires SPS measures to be "based on scientific principles and not maintained without sufficient scientific evidence". Article 5 goes on to require Members to base their SPS measures on a risk assessment which takes into account the available scientific evidence.

Members are also required to consider other objective factors when imposing SPS measures. For example, if identical or similar conditions prevail in different areas, the SPS Agreement encourages Members to treat the produce of those areas in the same way. ${ }^{30}$ Similarly, the Agreement requires Members to take into account the existence of pest or disease free areas when performing its risk assessment ${ }^{31}$ and to adapt any measures they adopt to the SPS characteristics of an area. ${ }^{32}$

\section{(b) Harmonisation}

A key goal of the SPS Agreement is to encourage the harmonisation ${ }^{33}$ of SPS measures between Members. To this end the Agreement requires Members to base their SPS measures on "international standards, guidelines or recommendations, where they exist" unless they wish to impose a "higher level of sanitary or phytosanitary protection". 34 "International standards, guidelines and recommendations" are defined as the standards, guidelines and recommendations established by the Codex Alimentarius Commission relating to food safety as well as those relating to animal and plant pests and diseases developed by other relevant international organisations. ${ }^{35}$

\section{(c) Equivalence}

Where there can be no harmonisation - either because there are no international standards, or where a Member has chosen its own higher "appropriate level of protection" (discussed below) - the SPS Agreement still seeks to minimise the compliance cost barriers created by SPS measures. Accordingly, a Member is obliged to accept the

30 SPS Agreement, Art 3.3.

31 SPS Agreement, Art 5.2.

32 SPS Agreement, Art 6.

33 SS Agreement, Annex A - Definition 2 defines "[h]armonisation" as "[t]he establishment, recognition and application of common sanitary and phytosanitary measures by different Members".

35 SPS Agreement, Annex A - Definition 3. 
SPS measures of other Members as equivalent, if such measures demonstrably achieve their appropriate level of SPS protection. ${ }^{36}$

\section{(d) Requirements to use the least trade restrictive measure possible}

Members are obliged to take into account the objective of minimising negative trade effects when determining their appropriate level of SPS protection. ${ }^{37}$ Furthermore, they are obliged to ensure that measures are not more trade restrictive than necessary to achieve the appropriate level of protection. ${ }^{38}$

\section{(e) Notification and implementation of measures}

Finally, the SPS Agreement requires changes in SPS measures to be published and notified to other Members. ${ }^{39}$ Members also have to establish "enquiry points" capable of answering questions from interested Members on local SPS rules. ${ }^{40}$ It also requires control, inspection and approval procedures to be carried out in a fair and expeditious manner. ${ }^{41}$

\section{The right of members to impose SPS measures}

\section{(a) The precautionary principle}

While Article 2.2 of the SPS Agreement requires measures to be based on sufficient scientific evidence, insufficiency of the science does not in itself preclude the adoption of precautionary measures. Article 5.7 provides:

In cases where relevant scientific evidence is insufficient, a Member may provisionally adopt sanitary or phytosanitary measures on the basis of available pertinent information, including that from the relevant international organisations as well as from sanitary or phytosanitary measures applied by other Members. In such circumstances, Members shall seek to obtain the additional information necessary for a more objective assessment of risk and review the sanitary or phytosanitary measure accordingly within a reasonable period of time.

\footnotetext{
36 SPS Agreement, Art 4.

37 SPS Agreement, Art 5.4.

38 SPS Agreement, Art 5.6.

39 SPS Agreement, Art 7 and Annex B.

40 Above $n 39$.

41 SPS Agreement, Art 8 and Annex C.
} 
Nevertheless, Article 5.7 makes it clear that such precautionary measures are applied only provisionally. A Member must seek to overcome the insufficiency of the scientific evidence within a reasonable period of time.

\section{(b) The "appropriate level of SPS protection"}

The SPS Agreement recognises the right of Members to set their own "appropriate level of sanitary and phytosanitary protection". 42 This means that where a risk has been identified, it is up to the Member concerned to set its own degree of protection against the risk.

Typically, in line with the harmonising thrust of the SPS Agreement, a Member might be expected to adopt, or at least base its measure on, an international standard. One would expect that in these cases Members would set their appropriate level of protection at the level embodied in the international standard. ${ }^{43}$ They are not bound, however, to this level. They may adopt a higher level provided that they comply with the disciplines on setting the appropriate level of SPS protection. ${ }^{44}$

Similarly, where there is no international standard, but where a Member has identified a risk, then the Member may set its own appropriate level of SPS protection, subject to the same disciplines. ${ }^{45}$

The disciplines on setting the appropriate level of SPS protection are contained primarily in paragraphs 4 and 5 of Article 5. It is, however, difficult to divorce the setting of the level of protection from the measure that embodies it. Accordingly, the rules affecting the adoption of SPS measures in paragraphs 3 and 6 of Article 5 as well as the basic rights and obligations in Article 2 are also important.

As mentioned above, Article 2.2 sets out the basic obligation that Members ensure their measures are supported by sufficient scientific evidence. Article 5.3 requires Members to take into account "relevant economic factors" when determining measures to achieve their appropriate level of protection. Article 5.4 encourages Members to "take

42 SPS Agreement, Annex A - Definition 5 defines the "appropriate level of sanitary or phytosanitary protection" as "[t]he level of protection deemed appropriate by the Member establishing a sanitary or phytosanitary measure to protect human, animal or plant life or health within its territory". The definition goes on to note "[m]any Members otherwise refer to this concept as the 'acceptable level of risk'".

43 As is discussed below at Part III D2(b), the Panel found that the test for whether a measure was "based on" an international standard was whether it reflected the same level of protection. The Appellate Body, however, rejected this test.

44 SPS Agreement, Art 3.

45 SPS Agreement, Art 5. 
into account the objective of minimising negative trade effects" when determining the appropriate level of protection. Article 5.5 seeks to ensure consistency in the application of the appropriate level of protection by requiring Members to avoid "arbitrary or unjustified distinctions" where these would create "discrimination or a disguised restriction on international trade". Finally, Article 5.6 requires Members to "ensure that [SPS] measures are not more trade restrictive than required to achieve the appropriate level of protection".

It is important to note that the right of Members to impose SPS measures is qualified with words such as "appropriate", "relevant economic factors", "take into account the objective", "arbitrary or unjustified" and "discrimination or disguised restriction". These words reflect the genesis of the SPS Agreement as a document agreed between trade negotiators, each with different requirements in terms of desired outcomes.

None of the tests can be defined with any precision without taking into account the circumstances of a particular case, and the value judgments of decision makers in such circumstances. It would be fair to say, therefore, that the exact nature of the balance in the SPS Agreement was not defined by the negotiators. The Agreement - like many international agreements - to some extent attempts to be all things to all people. What makes the SPS Agreement different is the compulsory nature of the WTO dispute settlement system. Ambiguities in the Agreement can remain only so long as they remain untested in dispute settlement.

\section{THE DECISION IN HORMONES}

The first test of the SPS Agreement by the WTO's new dispute settlement process came in Hormones. The issues in the case covered the most fundamental of the SPS Agreement provisions. The case is therefore very useful for evaluating exactly where the balance in the SPS Agreement between free trade and the right of Members to be risk averse actually lies.

\section{A Background}

The Hormones dispute evolved over a long period.46 In the 1970s European consumers developed a general concern about the use of hormones for growth promotion in cattle. This resulted from evidence that the illegal use of certain hormones in veal production had caused hormonal irregularities in a number of European

46 This history is usefully summarised in Hormones US Panel Report, above n2, paras 2.26-2.35 and Hormones Canada Panel Report, above n 2, paras 2.26-2.33. See also H Hammonds "A US Perspective on the EC Hormone Directive" (1990) 11 Mich J Int'l L, 840; and J Jackson "Dolphins and Hormones: GATT and the Legal Environment for International Trade After the Uruguay Round (1992) 14 U Ark Little Rock LJ, 429. 
adolescents. In 1980, in an attempt to restore consumer confidence in the beef market, EC Ministers undertook to ban the use of hormones in beef production for anything other than therapeutic purposes.

Over the subsequent decade, three Council Directives were issued prohibiting the use of three natural and three synthetic hormones for growth promotion purposes. These Directives were replaced in 1996 by a further Directive having the same effect. The ban affected only the six specific hormonal growth promotants and did not affect the use of the same hormones for therapeutic purposes. Furthermore, the ban applied only to the hormones where they had been administered to animals. The ban did not apply to residues of the hormones occurring naturally in food.

While the EC maintained that the ban was precautionary in nature, its principal basis appears to have been to address the consumer concerns. Scientific surveys completed on behalf of the EC Commission submitted that there was little health risk from the residues of the hormonal growth promotants in food. The results of these surveys mirrored the results of scientists elsewhere. For example, the Codex Alimentarius Commission was developing international standards relating to the use of hormonal growth promotants contemporaneous with the development of the European measures. The Codex studies suggested that there was little health risk.

By 1985, the US meat industry had become concerned with the application of the EC measures. On behalf of the industry, the US Government raised the issue of the EC Directives in the GATT under the Tokyo Round Standards Code. The US sought to have the issue referred to a technical experts group to examine the scientific basis of the measures. The EC, however, resisted these US moves and instead argued for the establishment of a dispute settlement Panel. In the EC's view, the measures regulated processes and production methods and could only be challenged to the extent that they circumvented other rules in the Standards Code. Neither mechanism was established. In 1989 the US retaliated by raising duties against certain European commodities. Later that year the EC requested GATT dispute settlement in respect of the US retaliation. This was blocked by the US.

The dispute over the use of hormones appears to have coloured the negotiation of the SPS Agreement during the Uruguay Round. This is evident from the EC's desire to include consumer concerns within the scope of the SPS Agreement. The European position on hormonal growth promotants also seems to have been reflected in the desire to have a wide discretion to deviate from international standards.

In any event, soon after the conclusion of the Uruguay Round the US challenged the EC's hormone ban under the newly negotiated dispute settlement procedures of the WTO. Canada also brought dispute settlement proceedings against the EC. New 
Zealand, Norway and Australia joined each proceeding as third participants. ${ }^{47}$ Contemporaneous with the American and Canadian requests, the EC again requested the formation of a dispute settlement Panel to consider the US retaliation. Before such a Panel was established, however, the US withdrew its retaliatory measures.

\section{B The Panel Decision}

The EC lost comprehensively at the Panel stage. As well as reaching conclusions on a number of procedural points, the Panel drew three substantive conclusions. These were: ${ }^{48}$

(i) The EC, by maintaining sanitary measures which are not based on a risk assessment, has acted inconsistently with the requirements contained in Article 5.1 of the SPS Agreement.

(ii) The EC, by adopting arbitrary or unjustifiable distinctions in the levels of sanitary protection that it considers appropriate in different situations which result in discrimination or a disguised restriction on international trade, has acted contrary to the requirements contained in Article 5.5 of the SPS Agreement.

(iii) The EC, by maintaining sanitary measures which are not based on existing international standards without justification under Article 3.3 of the SPS Agreement, has acted inconsistently with the requirements contained in Article 3.1 of that Agreement.

Shortly after the release of the Panel's decision the EC appealed all of the substantive (and most of the procedural) conclusions. The US and Canada also appealed on the grounds that the Panel's decision did not go far enough and should have made further findings of inconsistency with the SPS Agreement.

\section{The Appellate Body Decision}

With the exception of the allocation of the burden of proof, the Appellate Body largely confirmed the Panel's procedural conclusions. ${ }^{49}$ With respect to the substantive conclusions of the Panel, the Appellate Body maintained the first of the conclusions listed above but reversed the subsequent two. Thus the EC was still found to be in breach of its WTO obligations. Nevertheless, the Appellate Body report indicated that the EC had rather more flexibility in implementing their obligations than did the Panel decision.

47 The US also joined the Canadian dispute as a third participant and Canada joined the US dispute as a third participant. The way that the Panel dealt with the third party rights of the US and Canada in each of these situations was an issue in the Hormones appeal. This issue is not, however, explored in any depth in this paper.

48 Hormones US Panel Report, above n 2, para 9.1; Hormones Canada Panel Report, above n 2, para 9.1.

49 These procedural issues are generally not dealt with here. 


\section{Commentary}

\section{Burden of proof}

The general approach to the allocation of the burden of proof in WTO dispute settlement cases had been addressed by the Appellate Body in United States - Measures Affecting Imports of Woven Wool Shirts and Blouses from India ${ }^{50}$ (Wool Shirts). Wool Shirts involved a claim by India that the US had acted inconsistently with its obligations under the Agreement on Textiles and Clothing (the ATC). In its decision the Appellate Body: ${ }^{51}$

agree[d] with the Panel that it was up to India to present evidence and argument sufficient to establish a presumption that the transitional safeguard determination made by the US was inconsistent with its obligations under Article 6 of the ATC. With this presumption thus established, it was then up to the US to bring evidence and argument to rebut the presumption.

The Panel had called this "presumption" a "prima facie" case and it is by this term that the test in Wool Shirts is commonly described. The term prima facie used here has a particular meaning. In Wool Shirts the Appellate Body went on: ${ }^{52}$

a party claiming a violation of a provision of the WTO Agreement by another Member must assert and prove its claim. In this case, India claimed violation by the US of Article 6 of the ATC. We agree with the Panel that it, therefore, was up to India to put forward evidence and legal argument sufficient to demonstrate that the transitional safeguard action by the US was inconsistent with the obligations assumed by the US under Articles 2 and 6 of the ATC. India did so in this case. And, with India having done so, the onus shifted to the US to bring forward evidence and argument to disprove the claim.

With reference to Wool Shirts, the Panel in Hormones maintained that "in addressing the burden of proof under the SPS Agreement..., the initial burden of proof rests on the complaining party in the sense that it bears the burden of presenting a prima facie case of inconsistency with the SPS Agreement". ${ }^{53}$ The Hormones Panel went on to require that the complainants in that case put forward "factual and legal arguments" sufficient to "substantiate" their claims and "demonstrate violation of the SPS Agreement". 54

50 AB-1997-1, WT/DS33/AB/R (25 April 1997).

51 Wool Shirts, Appellate Body Report, above n 50, 13.

52 Wool Shirts, Appellate Body Report, above n 50, 16. Emphasis added.

53 Hormones US Panel Report, above n 2, para 8.51; Hormones Canada Panel Report, aboave n 2, para 8.54 .

$54 \quad$ Above $\mathrm{n} 53$. 
The Appellate Body was comfortable with this "straightforward" approach of the Panel. ${ }^{55}$ The Appellate Body was scathing, however, of the Panel's next assertion. Based on the conclusions discussed immediately above, the Panel had commented that there was an allocation of the evidentiary burden on the party defending an SPS measure. It examined the wording of the SPS Agreement to suggest why this should be so.

The Appellate Body said that the Panel's statement here reduced the reference to the Wool Shirts test to mere "lip-service". ${ }^{56}$ Noting that the allocation of the burden of proof often amounts to "a penalty", the Appellate Body reconsidered those provisions of the SPS Agreement referred to by the Panel and found no support for the Panel's general statement. ${ }^{57}$ The Appellate Body emphasised that the taking of SPS measures is a right of Members - the exercise of which should not be unjustifiably be penalised.

\section{Articles 3.1, 3.2 and 3.3 of the SPS Agreement}

\section{(a) General}

Having established the general allocation of the burden of proof, the Appellate Body turned to consider the Panel's interpretation of the relationship between Articles 3.1, 3.2 and 3.3. Article 3 as a whole is designed to stimulate the harmonisation of SPS standards amongst Members. Paragraphs 1, 2 and 3 of Article 3 read as follows:

1 To harmonize sanitary and phytosanitary measures on as wide a basis as possible, Members shall base their sanitary or phytosanitary measures on international standards, guidelines or recommendations, where they exist, except as otherwise provided for in this Agreement, and in particular in paragraph 3.

2. Sanitary or phytosanitary measures which conform to international standards, guidelines or recommendations shall be deemed to be necessary to protect human, animal or plant life or health, and presumed to be consistent with the relevant provisions of this Agreement and of the GATT 1994.

3. Members may introduce or maintain sanitary or phytosanitary measures which result in a higher level of sanitary or phytosanitary protection than would be achieved by measures based on the relevant international standards, guidelines or recommendations, if there is a scientific justification, or as a consequence of the level of protection a Member determines to be appropriate in accordance with the relevant provisions of paragraphs 1 through 8 of Article 5. Notwithstanding the above, all measures which result in a level of sanitary or phytosanitary

55 Hormones Appellate Body Report, above n 2, para 98.

56 Hormones Appellate Body Report, above n 2, para 99.

57 Above $\mathrm{n} 56$. 
protection different from that which would be achieved by measures based on international standards, guidelines or recommendations shall not be inconsistent with any other provision of this Agreement.

The Panel had made a particular observation with respect to the allocation of the burden of proof in Article 3:58

once a complaining party provides a prima facie case (i) that there is an international standard, and (ii) the measure in dispute is not based on this standard, the burden of proof shifts to the defending party.

At one level this can be seen to be an application of the Wool Shirts principle and this is more or less how the Panel presented the finding. ${ }^{59}$ Under the Panel's test a Member must establish general inconsistency with Article 3.1. However, such an allocation absolves the complaining party of the burden of considering the implications of the words "except as otherwise provided by this Agreement, and in particular the provisions in paragraph 3". This in effect is a reversal of the burden of proof.

In justifying this reversal, the Panel cited the practice of Panels and the Appellate Body in considering the general exception to the rules of GATT in Article XX of that Agreement. ${ }^{60}$ The Appellate Body dismissed this analysis. Rather than categorising the phrase "except as otherwise provided in this Agreement" as an "exception" in the nature of the Article XX general exception, the Appellate Body said that Article 3.1 "simply excludes from its scope the kinds of situations covered by Article 3.3".61

The Appellate Body's comments in this respect are based in a large part on their analysis of the relationship between paragraphs 1 and 3 of Article 3 (which is discussed later in the decision). The Appellate Body's analysis demonstrates that it views the ability of a Member to choose its own "appropriate level of protection" as an "important right", independent of the SPS Agreement's broad harmonising objective. ${ }^{62}$

58 Hormones US Panel Report, above n 2, para 8.87; Hormones Canada Panel Report, above n 2, para 8.90 .

59 See Hormonesi US Panel Report, above n 2, paras 8.84-8.85; Hormones Canada Panel Report, above n 2, para 8.87-8.88.

60 Hormones US Panel Report, above n 2, footnote 288; Hormones Canada Panel Report, above n 2, footnote 393 .

61 Hormones Appellate Body Report, above n 2, para 104.

62 Hormones Appellate Body Report, above n 2, para 172. 


\section{(b) "Based on" international standards}

While the EC had not sought to argue that its measures were based on any of these standards, ${ }^{63}$ the Panel found it necessary when turning to the substantive requirements of Article 3 to consider what it meant to be "based on" international standards as contemplated by Article 3.1. ${ }^{64}$ The Panel's reasoning in this respect was later reviewed by the Appellate Body. ${ }^{65}$

The Panel had found that there were international standards and guidelines with respect to five out of the six hormones considered in the case. When considering what it meant for measures to be "based on" international standards, the Panel examined the context in which the words were found. The Panel observed that Article 3.2 introduces a presumption that measures which "conform to" international standards are consistent with the SPS Agreement and GATT 1994. ${ }^{66}$ And further that Article 3.3 "explicitly relates the definition of sanitary measures based on international standards to the level of protection achieved by these standards. ${ }^{67}$ From this the Panel induced that "[o]ne of the determining factors in deciding whether a measure is based on an international standard is, therefore, the level of protection that measure achieves". ${ }^{68}$ The Panel continued: ${ }^{69}$

According to Article 3.3 all measures which are based on a given international standard should in principle achieve the same level of sanitary protection. Therefore, if an international standard reflects a specific level of sanitary protection and a sanitary measure implies a different level, that measure cannot be said to be based on the international standard.

63 See summary of EC submission in Hormonesi US Panel Report, above n 2, paras 4.77-4.84; Hormones Canada Panel Report, above n 2, paras 4.65-4.72.

64 This was apparently because of the close relationship that the Panel felt existed between Art 3.1 and 3.3. Article 3.3 did form the basis of ED argument.

65 One senses more reluctance on the part of the Appellate Body to investigate the meaning of "based on" in Art 3.1. As discussed below, the Appellate Body close their comments on the Panel's analysis of the term by saying "we are compelled to reject this premise [discussed below] as an error of law. The rest of the Panel's intricate interpretation and examination of the consequences of the Panel's litmus test will, however, have to be left for another day and another case". Hormones Appellate Body Report, above n 2, para 168.

66 Hormones US Panel Report, above n 2, para 8.72; Hormones Canada Panel Report, above n 2, para 8.75 .

67 Above n 66.

68 Above $\mathrm{n} 66$

69 Above n 66 
The Panel then concluded: ${ }^{70}$

that for a sanitary measure to be based on an international standard in accordance with Article

3.1 , that measure needs to reflect the same level of sanitary protection as the standard.

The logic here is questionable. It is one thing to induce that one of the factors to be taken into account when assessing whether a measure is based on an international standard is the level of protection. It is quite another to say that it is a determining factor - one that needs to be taken into account.

The Appellate Body picked up on this logical issue and strongly criticised the conclusion of the Panel. Nevertheless, in the Appellate Body's reckoning the Panel's fallacy was to equate "based on" with "conform to"71 - a conclusion not necessarily supported by the words that the Panel actually used in the decision. In the place of the Panel's test for measures "based on" international standards, the Appellate Body posited that a measure could be "based on" an international standard if it "adopt[ed] some, but not necessarily all of the elements of the international standard". ${ }^{72}$

\section{(c) Not based on international standards}

In any event the real Article 3 issue was not whether the measures were based on international standards. It was undisputed that they were not. With this in mind, the key question with respect to the five hormones in relation to which there were international standards was whether the EC had met the requirements of Article 3.3 for not basing its measures on international standards.

On their face, the disciplines of Article 3.3 appear to envisage two situations. The first is "if there is a scientific justification". The second is "as a consequence of the level of protection a Member determines to be appropriate in accordance with the relevant provisions of paragraphs 1 through 8 of Article 5". These situations are joined by "or" indicating that they are to be read as alternative situations.

The Panel, however, found that even though the first limb (scientific justification) did not explicitly refer to the risk assessment provisions of Article 5 (as the second limb did), it implied that a risk assessment was necessary anyway. This meant that for practical purposes there was only one route to justify deviation from international standards. The

70 Hormones US Panel Report, above n 2, para 8.73; Hormones Canada Panel Report, above n 2, para 8.76. (Emphasis in original).

71 Hormones Appellate Body Report, above n 2, para 162.

72 Hormones Appellate Body Report, above n 2, para 171. 
Appellate Body largely agreed maintaining that the risk assessment provisions set out in Article 5 were: ${ }^{73}$

intended as a countervailing factor in respect of the right of Members to set their appropriate level of protection .... The requirements of a risk assessment ... are essential for the maintenance of the delicate and carefully negotiated balance in the SPS Agreement between the shared, but sometimes competing, interests of promoting international trade and of protecting the life and health of human beings.

Accordingly the Appellate Body confirmed the Panel's assessment that the EC would have to show that its measures had been based on a risk assessment before it could benefit from the permissive terms of Article 3.3. The Appellate Body, like the Panel, thus turned to consider Article 5.

\section{Article 5 of the SPS Agreement}

\section{(a) General}

Article 5 deals with assessment of risk and determination of the appropriate level of SPS protection. Of particular relevance to the Hormones case were paragraphs 1, 2 and 5 of Article 5. Insofar as they were relevant to the case, these read as follows:

1. Members shall ensure that their sanitary or phytosanitary measures are based on an assessment, as appropriate to the circumstances, of the risks to human, animal or plant life or health, taking into account risk assessment techniques developed by the relevant international organisations.

2. In the assessment of risks, Members shall take into account available scientific evidence; relevant processes and production methods; relevant inspection, sampling and testing methods; prevalence of specific diseases or pests; existence of pest-or disease-free areas; relevant ecological and environmental conditions; and quarantine or other treatment.

5. With the objective of achieving consistency in the application of the concept of appropriate level of sanitary and phytosanitary protection against risks to human life or health, or to animal and plant life or health, each Member shall avoid arbitrary or unjustifiable distinctions in the levels it considers to be appropriate in different situations, if such distinctions result in discrimination or a disguised restriction on international trade.

The Panel had determined that Article 5 contemplated a distinction between two processes. The first - "risk assessment" - was to be a "scientific examination of data and

73 Hormones Appellate Body Report, above n 2, para 177. 
other factual studies". ${ }^{74}$ It was not, in the Panel's view, to involve "social value judgments made by political bodies". ${ }^{75}$

The second process - "risk management" - related to the determination and application of the appropriate level of sanitary protection by the Member when considering the extent and nature of the measures necessary. The Member was entitled in this process to take into account a number of factors, including social value judgments, but had to do so subject to certain disciplines - such as those requiring Members to avoid arbitrary and unjustifiable distinctions in Article 5.5. ${ }^{76}$

The Appellate Body rejected this distinction. It pointed out "that the term 'risk management' is not to be found in either Article 5 or any other provision of the SPS Agreement"77 and further that "the Panel's distinction, which it apparently employs to achieve or support what appears to be a restrictive notion of risk assessment, has no textual basis". ${ }^{78}$ Interestingly, the Appellate Body fails to mention (let alone take into account) the concept invoked by the Panel in justifying the distinction - the "appropriate level of protection".

Thus, the Appellate Body's rejection of the distinction drawn by the Panel allows the Appellate Body to mix the sorts of factors that on the Panel's test would have been separated. For example, the Appellate Body suggests that: ${ }^{79}$

there is nothing to indicate that the listing of factors that may be taken into account in a risk assessment of Article 5.2 was intended to be a closed list. It is essential to bear in mind that the risk to be evaluated in a risk assessment under Article 5.1 is not only risk ascertainable in a science laboratory operating under strictly controlled conditions, but also risk in human societies as they actually exist, in other words, the actual potential for adverse effects on human health in the real world where people live and work and die.

Significantly, this passage was instantly seized upon by the EC as justifying the taking into account of consumer concerns in imposing the ban. ${ }^{80}$

74 Hormones US Panel Report, above n 2, para 8.94; Hormones Canada Panel Report, above n 2, para 8.97.

75 Above $\mathrm{n} 74$.

76 Hormones US Panel Report, above n 2, paras 8.95-8.97; Hormones Canada Panel Report, above n 2, paras 8.98-8.100.

77 Hormones US Panel Report, above n 2, para 181.

78 Above $\mathrm{n} 77$.

79 Hormones US Panel Report, above n 2, para 187.

80 "WTO Ruling a Victory for European Consumers" EC Press Release, 16 January 1998. 


\section{(b) "Based on" a risk assessment}

Having rejected the Panel's assessment of the underlying structure of Article 5, the Appellate Body went on to consider the question of whether the EC measures were "based on" a risk assessment as required by Article 5.1. All parties to the dispute agreed that there had been scientific studies done on the health effects of the hormones in question both in international fora (such as Codex) and by the Europeans themselves. The complainants pointed out, however, that it was important to distinguish between merely having a risk assessment and basing one's measures on it. ${ }^{81}$

With this in mind, the Panel had gone on to suggest that (in addition to a substantive requirement) there was a "minimum procedural requirement" in Article 5.1 to the effect that "the Member imposing the sanitary measure needs to submit evidence that it at least took into account a risk assessment when it enacted or maintained its sanitary measure for that measure to be considered as having been based on a risk assessment". ${ }^{82}$

The Appellate Body rejected this as "unnecessary and an error of law as well". 83 For the Appellate Body the test of whether a measure was "based on" a risk assessment was purely a substantive one. Modifying the test proposed by the Panel, the Appellate Body held that to be "based on" an assessment in this case meant that there had to be a "rational relationship" between the conclusions of the assessment and the measure imposed. ${ }^{84}$ The Appellate Body went on to underline that a risk assessment need not be based on "mainstream" scientific opinion. ${ }^{85}$ Instead, an assessment's conclusions could be based on a "divergent opinion coming from qualified and respected sources". ${ }^{86}$ The decision of the Appellate Body accordingly indicates that there is considerable flexibility available to a Member when considering how to translate a risk assessment into the imposition of a measure.

Despite this flexibility the Appellate Body was still unable to find any rational relationship between the EC measures and the studies that had been done on the use of

81 See for example Hormones US Panel Report, above n 2, para 4.111.

82 Hormones US Panel Report, above n 2, para 8.113; Hormones Canada Panel Report, above n 2, para 8.116 .

83 Hormones US Panel Report, above n 2, para 189.

84 Hormones US Panel Report, above n 2, para 193.

85 Hormones US Panel Report, above n 2, para 194.

Above $\mathrm{n} 85$. 
hormonal growth promotants. The Appellate Body accordingly upheld the key decision of the Panel that the EC was in breach of its international obligations. ${ }^{87}$

In reaching its decision it is clear that the Appellate Body was unimpressed (as had been the Panel) with the invocation of the precautionary principle by the EC in support of their argument that the measures had been based on a risk assessment. The Appellate Body concurred with the Panel's assessment that the precautionary principle had found expression in Article 5.7 of the SPS Agreement, and while this did not necessarily exhaust the relevance of the precautionary principle to the Agreement, it was clear that the precautionary principle could not override the clear wording of Articles 5.1 and 5.2. ${ }^{88}$ The precautionary principle was not, therefore, of any assistance to the EC.

\section{(c) "Arbitrary or unjustifiable distinctions" and "discrimination" or"disguised restriction on international trade"}

The Panel and Appellate Body next turned to consider the disciplines on setting the appropriate level of protection. When considering these disciplines, the Panel focused solely on Article 5.5. ${ }^{89}$ In reviewing the Panel's decision, the Appellate Body was constrained to do the same. ${ }^{90}$ The Appellate Body (like the Panel) determined that the application of Article 5.5 required consideration of three separate (but cumulative) factors. ${ }^{91}$ These were firstly, that a Member must have chosen its own appropriate level of protection in different situations. Secondly, the levels of protection deemed appropriate in different situations must exhibit arbitrary or unjustifiable differences when compared to the treatment of the different situations. Finally, the arbitrary or unjustifiable differences must result in discrimination or a disguised restriction on international trade.

On the first issue the Appellate Body agreed with the Panel's finding that the EC had set different levels of protection in different, but comparable, situations. The Appellate Body identified three examples. The first was the distinction between the complete ban

87 Hormones Appellate Body Report, above n 2, paras 197, 253.

88 Hormones Appellate Body Report, above n 2, para 189.

89 As is discussed below, the Panel found inconsistency with the provisions of Art 5.5. Exercising the prerogative of judicial economy, the Panel elected not to continue in its assessment to consider Art 5.6 (although this provision had been the subject of argument before it). See Hormones US Panel Report, above n 2, para 8.247; Hormones Canada Panel Report, above n 2, para 8.250.

90 Although, as will be seen, the Appellate Body reversed the Panel's decision on Art 5.5, they felt that there was inadequate factual basis for them to proceed to consider Art 5.6. See Hormones Appellate Body Report, above n 2, para 251.

91 Hormones Appellate Body Report, above n 2, para 214. 
on beef treated with hormones and the complete lack of regulation on beef (and other foods) having endogenously high levels of hormone residues. The second was between the complete ban on hormonal growth promotant residues and the allowance of residues from the use of the same hormones for therapeutic purposes on the other. The final situation involved a comparison of the ban on hormonal growth promotant residues and the permitting of the residues of two agricultural chemicals which had similar effects to the hormones.

On the first of these examples, the Appellate Body reversed the Panel's finding that the distinction was arbitrary or unjustified. The Appellate Body felt that there was a "fundamental distinction" between added and naturally occurring hormones. ${ }^{92}$ The Appellate Body went on to say that to regulate the consumption of naturally occurring hormones "entails such a comprehensive and massive intervention into the ordinary lives of people as to reduce the comparison itself to absurdity". 93

The Appellate Body also reversed the Panel's determination in relation to the distinction between hormones used for therapeutic and zootechnical purposes and those added for growth promotion. The Appellate Body noted that there were differences between the scale and frequency of the treatment. ${ }^{94}$ It also noted that typically it was breeding cattle - rather than those intended for slaughter - that were therapeutically treated with hormones. ${ }^{95}$ And finally the Appellate Body noted that the mode of treatment was different. Unlike hormonal growth promotants, therapeutic hormones were administered in the presence of a veterinarian. ${ }^{96}$ Based on these factors the Appellate Body found it impossible to say that the distinctions were "arbitrary or unjustifiable".

The Appellate Body did find, however, that the distinction between the two agricultural chemicals and the hormonal growth promotants was arbitrary or unjustifiable. In relation to this distinction the Appellate Body considered the third element of the Article 5.5 test.

The Appellate Body first noted that the determination of whether an arbitrary or unjustified distinction caused "discrimination or a disguised restriction on international

92 Hormones Appellate Body Report, above n 2, para 221.

93 Above $\mathrm{n} 92$

94 Hormones Appellate Body Report, above n 2, para 223.

95 Above $\mathrm{n} 94$.

96 Hormones Appellate Body Report, above n 2, para 224. 
trade" depended on the circumstances of each case. ${ }^{97}$ It noted, however, that the existence of arbitrary or unjustifiable distinctions could operate as "warning signals", but that close scrutiny was still required. ${ }^{98}$ The Appellate Body went on to consider the Panel's assessment that the distinction between the agricultural chemicals and the hormonal growth promotants seemed aimed, at least in part, at the protection and promotion of the domestic meat industry. The Appellate Body considered the facts on which this assessment had been made but rejected the assertion of the Panel. It did not, however, dispute the appropriateness of the discussion. Nor did the Appellate Body go on to consider how else the measures could be discriminatory or what else the measures may be disguising. The Appellate Body thus seems to imply that the litmus test for "discrimination or disguised restriction" is the effect that measures have in protecting domestic industry.

\section{Other provisions}

The Panel refrained from considering Articles 2.2 and 5.6 of the SPS Agreement, even though these provisions had been the subject of argument before them. The Appellate Body "agree[d] with the Panel's application of the notion of judicial economy". ${ }^{99}$ It too reached no conclusions on these two articles.

While the exercise of judicial economy used to avoid addressing Article 5.6 is understandable, ${ }^{100}$ it is very unfortunate that the Panel and Appellate Body failed to address Article 2.2. The lack of an answer to the key question of whether the measures were imposed without a sufficient scientific justification leaves it open for the decision to become something of an "interim injunction". The absence of a finding on Article 2.2 is particularly striking given that the Appellate Body held that the EC measures had no rational relationship to the scientific evidence that had been compiled. ${ }^{101}$ This

97 Hormones Appellate Body Report, above n 2, para 240.

98 Hormones Appellate Body Report, above n 2, para 215.

99 Hormones Appellate Body Report, above n 2, para 250.

100 As is noted above, the Panel had found inconsistency with Art 5.5 and thus felt it unnecessary to continue to examine whether the measures were more trade restrictive than necessary in accordance with Art 5.6. See above n 89. While the Appellate Body reversed the finding of the Panel on Art 5.5, they were unable to consider Art 5.6 because of inadequate factual information. See above n 90 .

101 See text above at n 87. Interestingly the Appellate Body's exercise of judicial economy in this respect was not followed by the Panel considering Australia - Salmon. In that case, the Panel found that a breach of Art 5.1 implied a breach of the general obligation in Art 2.2. See Australia - Salmon, Panel Report, above n 29, para 8.99. The Australia - Salmon decision was, subject to review by the Appellate Body at the time of writing. 
significantly limits the amount that the case reveals about the balance in the Agreement. It also has important implications in terms of the ability of the WTO dispute settlement system to actually settle disputes.

\section{E The Aftermath of the Decision}

The interim nature of the decision seems to have been played out in its aftermath. Immediately after the release of the decision, the Office of the US Trade Representative welcomed the findings and called them "a sign that the WTO Dispute settlement system can handle complex and difficult disputes". ${ }^{102}$ At the same time, the EC Commission hailed the decision as a victory for European consumers. ${ }^{103}$ Later, on the same day that the Dispute Settlement Body adopted the Hormones Panel and Appellate Body reports, the EC indicated that its measures would remain in place while it completed risk assessments on each of the hormones subject to the dispute that would be "complementary" to the Appellate Body's decision. ${ }^{104}$ The decision was thus claimed as a victory by both sides.

The EC subsequently claimed that the completion of these risk assessments, together with legislative action needed to implement their conclusions, would require the existing measures to remain in place for approximately four years. The US and Canada understandably objected to this and claimed that the EC should only have ten months to revoke the existing import prohibition. The issue of what was a "reasonable period of time" for the implementation of the Hormones decision thus came to be decided in arbitration under Article 21.3(c) of the Understanding on the Rules and Procedures Governing the Settlement of Disputes (the Dispute Settlement Understanding or DSU). ${ }^{105}$

In the end the arbitrator applied the "guideline" in Article 21.3(c) of the DSU and found that 15 months from the date of adoption would be a reasonable period of time in which to implement the recommendations and rulings of the Dispute Settlement Body. ${ }^{106}$ The tenor of the arbitrator's discussion suggests that he would prefer to see the EC revoke their measures. For example, the arbitrator recalled that "Article 3.7 of the DSU provides in relevant part 'the first objective of the dispute settlement mechanism is usually to secure

102 "Appellate Body Finds EC Hormone Ban Inconsistent with WTO Obligations Under SPS Agreement" US Trade Representative Press release, 15 January 1998.

103 EC Press release, above n 80.

104 Reported in Midday Express (European Commission Newsletter available on the Internet at http://europa.eu.int/en/comm/spp/me/midday.html) 13 March 1998; also in Reuters EC Report Document IP/98/253 (Brussels, 13 March 1998).

105 See above n 29.

106 Hormones Report of the Arbitrator, above n 29, para 48. 
the withdrawal of the measures concerned if these are found to be inconsistent with the provisions of any of the covered agreements'". ${ }^{107}$ The arbitrator noted, however, that it was "not within [his] mandate under Article 21.3(c) of the DSU, to suggest ways or means to the European Communities to implement the recommendations and rulings of the Appellate Body Report and the Panel Reports". ${ }^{108}$

Indications are that the EC has begun its risk assessments. The stated aim of these assessments is to find a justification for the hormone ban - in the arbitration the EC argued: ${ }^{109}$

The Appellate Body did not find that the EC's import prohibition was per se inconsistent with the SPS Agreement, but only that the EC had violated its obligations under the SPS Agreement by not conducting a proper risk assessment within the meaning of Article 5.1 as the basis for the import prohibition. The EC is entitled, therefore, to bring its measure into conformity with the SPS Agreement by basing it on a properly specific risk assessment, as this concept has now been clarified for the first time by the Appellate Body.

While this was not looked upon favourably by the arbitrator, ${ }^{110}$ it is nonetheless likely that the EC will find a justification for its ban. When this happens, and the ban is reengineered accordingly, it is not unlikely - unless some political accommodation is reached - that the complainants in the original Hormones case will again challenge the EC measures, this time questioning the "sufficiency" (or otherwise as the case may be) of the scientific evidence. It will only be this second round of litigation that will decide who actually wins the case. ${ }^{111}$

\section{THE BALANCE IN THE SPS AGREEMENT AFTER HORMONES}

Because the Uruguay Round negotiators did not precisely define the balance between the Members' right to be risk averse and the objective of minimising negative trade effects, the ultimate drawing of the line was left up to the WTO's dispute settlement regime. Being the first dispute settlement decision on SPS Agreement, the decision in Hormones reveals much about where the line will come to be placed.

107 Hormones Report of the Arbitrator, above n 29, para 38. Emphasis added.

108 Above n 107.

109 Written Submission of the European Communities, para 64, cited the Hormones Report of the Aribtrator, above n 29, para 8.

110 See Hormones Report of the Arbitrator, above n 29, paras 38-42.

111 The problem of not actually resolving the dispute is dealt with by Dale McNeil - one of the US lawyers involved in the Hormones case - in a contribution to a Washington Law Firm newsletter: see McNeil, above $n 2$. 


\section{A Allocation of the Burden of Proof}

In allocating of the general burden of proof under the SPS Agreement, the Appellate Body stressed that the ability of Members to take SPS measures was an "important right". The Appellate Body reasoned that, as such, it should not be unjustifiably penalised by some special allocation of the evidentiary burden.

As noted above, the Appellate Body strongly criticised the conclusion of the Panel that the evidentiary burden somehow fell upon the Member defending the imposition of an SPS measure. From a logical point of view, the Appellate Body's criticism of the Panel in this respect is probably justified. If, as the Panel asserted, the initial burden of "asserting and proving" the claim with argument "sufficient to demonstrate" that there is inconsistency with an international obligation lies on the complaining party, then it is plainly incorrect to say that the "evidentiary burden" is allocated to the defending party. At a minimum the "evidentiary burden" is shared by both parties - one must establish a case, the other must refute it (albeit at different stages of a Panel's investigation).

However, on closer examination, the Panel's mistake in this respect may have been more a careless use of language than an attempt to reverse the burden of proof. It clearly recognised, for example, that the complaining party would have to "substantiate its claim that a sanitary measure is inconsistent with the SPS Agreement" before the defending party would bear its evidentiary burden. ${ }^{112}$

It may be therefore that the Panel's general statement merely reflects an implicit assessment about the nature of SPS cases. In an SPS case it will frequently be simple to establish a prima facie case (in the Wool Shirts sense) of inconsistency. This flows from the fact that consistency with the SPS Agreement often flows from the taking by Members of certain positive acts - for example, the performance of a risk assessment; the adaption of measures to the SPS characteristics of an area; or the taking into account of certain criteria when setting the appropriate level of protection. In the absence of evidence from the defending party that such acts have occurred, the complainant's burden of proof will be met. Viewed in this light the Panel's assertion about the allocation of evidentiary burdens can be seen more as a statement about the practicalities of an SPS case, rather than as an erroneous statement of law.

It may be therefore that the significance of the Appellate Body's stress on the "important right" of Members in adjusting the balance in the SPS Agreement may be more apparent than real. Indeed, a consistent application of the burden of proof across the whole of the WTO Agreement does as much for the transparency and predictability

112 Hormones US Panel Report, above n 2, para 8.51; Hormones Canada Panel Report, above n 2, para 8.54 . 
of the system as would the allocation of the burden of proof on a Member defending a measure. The Appellate Body's approach does nevertheless reflect its general leaning towards allowing Members greater freedom to impose SPS measures rather than to defend the disciplines that would facilitate more open trade. The Appellate Body's approach here, and in a number of other places,

clearly allows Members to take a cautious approach to protecting plants, animals and people. ${ }^{113}$

\section{B Harmonisation}

While the impact of the allocation of the general burden of proof may be more apparent than real, the allocation of the burden in respect of measures deviating from international standards may be of greater importance.

Harmonisation of SPS measures amongst Members was one of the key goals from the beginning of the SPS negotiations in the Uruguay Round. A harmonised approach to protecting human animal and plant health would minimise the compliance costs that traders faced. They would know exactly what to expect.

The Panel's analysis of Article 3 had attempted to give effect to this harmonising goal. The Panel saw harmonisation as an obligation - the wording of Article 3.1 said that "Members shall base their sanitary or phytosanitary measures on international standards, guidelines or recommendations, where they exist" (emphasis added). It accepted that there was an exception to this general rule - denoted by the use of the word "except" in Article 3.1.

The Appellate Body, however, turned this analysis on its head. The Appellate Body played down the harmonising role of international standards and emphasised the ability of Members to impose their own measures. It did this by revising the Panel's assessment

113 Indeed, while the Appellate Body did not entertain the EC's arguments in relation to the direct application of the precautionary principle, a number of aspects of the Appellate Body's analysis seem to be guided by the precautionary approach. For example, the Appellate Body's allocation of the burden of proof on the Members complaining about an SPS measure is consistent with the emerging international law on the precautionary principle. In his First report on prevention of transboundary damage from hazardous activities, UNGA Document A/CN.4/487/Add.1 (3 April 1998) International Law Commission Special Rapporteur Pemmaraju Sreenivasa Rao noted in relation to the precautionary principle that "[t]he principle also suggests that where there is an identifiable risk of serious or irreversible environmental harm, ... it may be appropriate to place the burden of proof on the person or entity proposing the activity that is potentially harmful to the environment".Hormones Report of the Arbitrator, above n 29, para 48. Hormones Report of the Arbitrator, above n 29, para 48. Hormones Report of the Arbitrator, above n 29, para 48. 
of the allocation of the burden of proof. The Appellate Body went on to read down the word "shall" in Article 3.1 and stress as an independent right the ability of Members to deviate in accordance with Article 3.3 and to take action to impose a higher level of protection. The Appellate Body decision thus suggests that there is a significantly different balance in Article 3 of the SPS Agreement from that which the Panel had found.

Of course, harmonisation still carries advantages for Members considering imposing SPS measures. It is, for example, easier (and cheaper) to utilise already-developed standards than to develop one's own. Members will accordingly continue to harmonise their SPS measures. But the Appellate Body's assessment of what it means to "base" measures on an international standard weakens the residual potential of harmonisation to lower barriers to trade. All a Member need now do to base its measures on international standards is adopt "some, but not necessarily all" of the elements of the standard. The vagueness of this test, in addition to the Appellate Body's approach to the burden of proof, means that harmonisation (in the sense envisaged by the definition of the term in the SPS Agreement) is now largely optional. The ability of harmonisation to reduce the number of unnecessary barriers to trade is consequently restricted.

The Appellate Body's approach to Article 3.3, however, gives more hope to those who would wish to see greater transparency in the application of SPS measures. Even despite some ambiguity in its drafting, the Appellate Body found that a Member would have to justify its measure with reference to a risk assessment whenever it sought to deviate from international standards.

This finding came at the cost of reducing some of the words in Article 3.3 to inutility. ${ }^{114}$ While this means that the Appellate Body here failed to accept some of its own advice, ${ }^{115}$ the alternative - allowing Members to base measures on a risk assessment in some circumstances but to adopt some alternative process in other situations - would

114 This point was not lost on the Appellate Body. They said "[w]e are not unaware that this finding tends to suggest that the distinction made in Art 3.3 between the two situations may have very limited effects and may, to that extent, be more apparent than real". Hormones Appellate Body Report, above n 2, para 176.

115 In its first decision, the Appellate Body referred to the 1969 Vienna Convention on the Law of Treaties and noted that "[o]ne of the corollaries of the 'general rule of interpretation' in the Vienna Convention is that interpretation must give meaning and effect to all the terms of a treaty. An interpreter is not free to adopt a reading that would result in reducing whole clauses or paragraphs of a treaty to redundancy or inutility". US - Reformulated Gasoline, above n 4, 23. The subsequent jurisprudence of the Appellate Body often reiterates the importance of this textual approach - see for example the Reports of the Appellate Body in Japan - Taxes on Alcoholic Beverages WT/DS8/AB/R; WT/DS10/AB/R; WT/DS11/AB/R (4 October 1996), 12; and in India - Patent Protection for Pharmaceutical and Agricultural Chemical Products WT/DS50/AB/R (19 December 1997), para 45. 
have devastated the procedural integrity of the SPS Agreement. Given this choice, the Panel and Appellate Body reached the best conclusion available on this issue. ${ }^{116}$

\section{The Risk Assessment}

Despite the fact that the Panel and Appellate Body declined to address the sufficiency of the scientific evidence in the case, the Appellate Body still abrogated the role that science could play in adding transparency and predictability to the imposition of SPS measures by rejecting the Panel's distinction between risk assessment and risk management for the purposes of Article 5. This is unfortunate given that the approach taken by the Panel was an intuitively attractive means through which to analyse the terms of Article 5 in that it provided a tidy, practical means through which the Article 5 obligations could be given effect to by a Member. That is to say, the risk assessment/risk management distinction broke the Article 5 procedure down into two steps. First, a Member should seek to identify any actual health risks. By itself, this would seem to be an inherently scientific process - or in any event not one involving extraneous pressures from unscientifically based popular consumer perception. Second, a Member, having identified a risk, could set the "appropriate level of protection" against it. Because this would be a political decision, the Member could take account of the concerns of its consumers. If the Member could identify no risk, then it would not be able to impose an SPS measure. This would not, however, necessarily preclude the Member from adopting another kind of measure which transparently addressed the consumer concern. ${ }^{117}$

In contrast to this two stage approach, the Appellate Body mixes the requirements of paragraphs 1 through 6 of Article 5. This mixing allows factors other than scientific evidence (perhaps even subjective ones) to be taken into account when performing a risk assessment. This reduces the moderating effect that scientific discipline could have had on the Article 5 process. It removes some of the certainty that would have been created had the Panel's distinction remained.

Further, like the test for measures "based on" an international standard, the test for "based on" a risk assessment is now considerably relaxed. A Member's measures need not conform to the conclusions of a risk assessment. Nor need they be based on

116 Some would argue otherwise. The main reason for the strict textual approach that the Appellate Body has taken elsewhere is that this ensures the predictability of WTO rules. It also serves to send a message to trade negotiators that the text of an agreement needs to be robust and unambiguous. With this in mind, a literal interpretation of Art 3 - while devastating to the SPS Agreement - would ensure that future negotiations would result in better drafted agreements and greater overall predictability.

117 Such a measure, would, of course be subject to other disciplines - for example those in the TBT Agreement. Such disciplines are generally not dealt with here but see below n 126. 
"mainstream" science. Instead all a Members measures have to do is bear a "rational relationship" to the risk assessment, which itself might be drawn from a "divergent opinion" - although, admittedly, one coming from a qualified and respected source.

While this too detracts from the certainty that could otherwise have developed had the Panel's approach been adopted, the Appellate Body's reassessment in this respect seems broadly justified. The "rational relationship" test is a useful one and has been successfully applied by the Panel in Australia - Measures Affecting Importation of Salmon. ${ }^{118}$ The emphasis on non-mainstream scientific views too seems appropriate. Science is not good at providing 100 per cent certainty. The EC arguments in relation to the precautionary principle identified situations where health hazards only became apparent long after substances or products had been assumed to be safe - Cyclamates, saccharin, phehformin, numerous pesticides, asbestos, thalidomide, hormone DES and more recently E Coli and BSE. It is only by taking into account all the scientific evidence (including dissenting views) that Members can protect themselves from the risk of the predominant scientific view being wrong. The Appellate Body's consideration of the rules affecting risk assessments thus favours the right of Members to impose somewhat "precautionary" SPS measures in situations where there is scientific debate.

\section{Disciplines on the Appropriate Level of Protection}

The real mischief in the Hormones decision lies in the Appellate Body's approach to Article 5.5.

Simply from a logical point of view, the reasoning of the Appellate Body in reversing the Panel's determinations on Article 5.5 is questionable. It will be recalled that the Panel had found the distinction between administered and naturally occurring hormones to be arbitrary or unjustified. The Appellate Body reversed this and said that the "fundamental difference" between these two processes, and the governmental intervention that would be required to regulate the two equally, meant that the comparison itself was "reduced to absurdity". This cannot be correct. The comparison between the residues of hormones naturally occurring in meat and residues otherwise so occurring that all the scientific evidence suggested were exactly the same can hardly be absurd. Governments regularly intervene in the "ordinary lives of people" to protect them from unsafe food. This is part of the nature of sanitary measures. Instead, the "absurdity" that the Appellate Body highlights simply points to the arbitrariness of the distinction.

Similarly, the Appellate Body consideration of the distinction between hormonal growth promotants and therapeutic hormones is suspect. The Appellate Body felt that controls on the mode of administration meant that the distinction between these

118 See Australia - Salmon Panel Report, above n 29, paras 8.93-8.100. 
situations was not arbitrary or unjustified. But again, the fact that cattle therapeutically treated with hormones are not typically slaughtered can hardly be relevant. The point in the case was that such animals do become part of the human diet. Likewise, the mode and frequency of administration should not have been a relevant factor given that the final product - the meat - did not exhibit different levels of hormonal residues or any other quantitative or qualitative differences.

These findings clearly affect the nature of the balance in the SPS Agreement. Article 5.5 is one of the principal disciplines designed to ensure the transparency and predictability of SPS measures. Where, as appeared to be the case in the Hormones situation, seemingly arbitrary distinctions (ones where the scientific evidence said the two products were the same) are labelled "fundamentally different", the effectiveness of the disciplines is severely limited.

Moreover, this sort of reasoning has huge potential to affect other aspects of WTO rules. For example the traditional approach of dispute settlement Panels has been to reject claims that the processes or production methods used to produce a trade item are sufficient to distinguish it from another item that is physically identical. This approach has prevailed since the earliest days of GATT dispute settlement ${ }^{119}$ and became part of GATT culture. ${ }^{120}$

The reason why process and production method-based analyses were rejected was recently restated by the Panel in United States - Import Prohibition on Certain Shrimp and Shrimp Products ${ }^{121}$ (Shrimp-Turtle). In their decision the Panel noted the unpredictability that would be created if a process and production method type analysis were adopted and rejected an argument based on such an approach. ${ }^{122}$ In the Panel's view, if such an analysis were used then "[m]arket access for goods could become subject to an increasing number of conflicting policy requirements for the same product and this would rapidly lead to the end of the WTO multilateral trading system". ${ }^{123}$

119 See for example Belgian Family Allowances (1953) BISD 1S/59.

120 The impact of this analysis has been particularly marked in "trade and environment" cases - for example the famours Tuna-Dolphin Panels (see above n 4) where US legislation prohibiting imports for tuna not caught by a means that complied with US dolphin protecting rules was considered and more recently Shrimp-Turtle Panel Report, above n 4, which involved very similar facts. The developing jurisprudence in relation to trade and environment cases (interestingly including Hormones) is usefully reviewed in J Cameron \& K Campbell "Challenging the Boundaries of the DSU through Trade and Environment Cases", in Cameron \& Campbell, above n 16, 204.

121 See above $\mathrm{n} 4$.

122 Shrimp-Turtle Panel Report, above n 4, para 7.45.

123 Shrimp-Turtle Panel Report, above n 4, para 7.45. 
Of course, the Appellate Body's process and production method-based approach to Article 5.5 of the SPS Agreement may not escape into other WTO provisions. Indeed in the Hormones decision itself, the Appellate Body cautioned that the jurisprudence of one Agreement could not be "casually imported" into an analysis of another. ${ }^{124}$ But it remains an open question. The reasoning in Hormones may offer a dangerous precedent. Another questionable aspect of the Appellate Body's Article 5.5 analysis relates to the approach that it took in indicating that the litmus test for "discrimination or disguised restriction on international trade" was the effect that a measure had in protecting domestic industry from import competition.

Given the facts of Hormones it is unsurprising that the Appellate Body found no protectionist intent on the part of the EC. Notwithstanding the Panel's determination that the measures were protectionist, there seems to be little evidence that this was the case. Instead the EC measures were based squarely on the concerns of European consumers. What the reasoning of the Panel and of the Appellate Body fails to recognise is that these can be disguised restrictions just as much as protectionist measures.

Again, the Appellate Body's reasoning does little to further the SPS Agreement. The decision reduces the transparency in the application of SPS measures by further obfuscating and diluting the disciplines of the Article 5 process.

\section{E The Precautionary Principle}

The Panel and Appellate Body were correct to avoid addressing the EC's invocation of the precautionary principle in any real depth in their decisions. The manner in which the EC invoked the precautionary principle in the case was tenuous. The SPS Agreement envisages two situations. The first is where the science is sufficient. In such a situation, Members may take measures against any identifiable risks, basing such measures on an assessment taking into account the scientific evidence. The second situation is where the science is insufficient. In such a situation, Members may still provisionally apply precautionary measures while seeking information to make a "more objective" assessment of the risks.

The EC "precautionary principle" argument proceeded to say, however, that the science was sufficient. They just didn't trust it. Their approach was so precautionary that they imposed measures on the basis that the scientific evidence might be shown to be wrong. If such an argument had been accepted by the Appellate Body then there could be no predictability in the application of SPS measures as their application would depend on the application of purely subjective criteria. One might also observe that the EC

124 Appellate Body report para 239. 
moves the precautionary principle away from its traditional basis in scientific uncertainty to a new level based on an aversion to scientific data. ${ }^{125}$

Nevertheless, the situations cited by the Europeans are still troubling. The question is how one allows for the risk of science being wrong to be taken into account without taking away the transparency and predictability that the SPS Agreement seeks to bring to the application of SPS measures. The answer must surely be not to treat measures which protect against science "being wrong" as SPS measures. SPS measures should be science based, where the science is sufficient. Where a Member (or more precisely, a Member's consumers) has an aversion to the scientific data, then it should be empowered to protect itself against whatever risks it perceives. For example if consumers do not like a particular process or production method, then information in the marketplace should enable them to avoid products created through such a procedure. An efficient market place might achieve this with minimal action by regulators - voluntary negative labelling might allow consumers to choose products that do not exhibit the factors to which they are averse. Regulatory action would be kept to ensuring that claims were not misleading. The existence of a less efficient market might require regulators to empower consumers by mandatory labelling. ${ }^{126}$

\section{CONCLUSION}

The SPS Agreement was developed to ensure that SPS justifications were not used to disguise otherwise unjustifiable restrictions on trade. The final text struck a balance between the right of Members to impose SPS measures and the objective of facilitating more open trade. This balance, however, was not made explicit. Instead, it remained cloaked in the vague wording of a negotiated outcome.

125 Traditionally, the precautionary principle has been defined along the lines of Principle 15 of the Rio Declaration in Environment and Development (issued at the United Nations Conference on Environment and Development, Rio de Janeiro, 14 June 1992) which reads: "[i]n order to protect the environment, the precautionary approach shall be widely applied by States according to their capabilities. Where there are threats of serious or irreversible damage, lack of full scientific certainty shall not be used as a reason for postponing cost-effective measures to prevent environmental degradation". This clearly focuses on the insufficiency of scientific evidence, rather than on an aversion to it.

126 Such an approach would, of course, have to grapple with the disciplines in Art 2.2 of the TBT Agreement that measures not be adopted with a view to creating unnecessary obstacles to trade. There are issues relating to whether the labelling in these circumstances would meet the TBT test, however, they are not dealt with here. It is interesting to observe, however, that Canada argued at one point that "labelling might seen to be a reasonable alternative to the prohibition applied by the EC on the use of these hormones", Hormones Canada Panel Report, above n 2, para 4.309. 
In Hormones, the WTO dispute settlement system was given with the task of clarifying the nature of the balance in the SPS Agreement.

The SPS Agreement sets up a two stage system for testing whether SPS measures are justified. The first stage requires that SPS measures be developed through a sound procedure. The Panel in Hormones took a strict approach to the procedural disciplines. The Panel stressed the importance of harmonisation and maintained that unharmonised measures would need to be justified by a purely scientific risk assessment. The Appellate Body stepped back from this approach, relaxing the procedural requirements. Harmonisation becomes optional. The risk assessment need not be purely scientific.

The second aspect of the SPS Agreement's disciplines is its requirement that SPS measures generally not be maintained without sufficient scientific evidence. Neither the Panel nor the Appellate Body properly grappled with this issue. The Appellate Body's approach, however, weakens the moderating role that science could have played on the application of SPS measures.

The Appellate Body's approach swung the balance too far. By increasing the degree to which subjective assessments can be reflected in SPS measures, the decision reduces the transparency and predictability of such measures. This allows Members to placate the concerns of their consumers but reduces trade opportunities. While consumers may feel more comfortable, it is difficult to see how the taking into account of subjective concerns could better protect those same consumers from genuine risks. Instead it increases the likelihood of SPS measures becoming disguised restrictions on trade. 